\title{
Insulin-like growth factor I (IGF-I) in a growth-enhanced transgenic (GH-overexpressing) bony fish, the tilapia (Oreochromis niloticus): indication for a higher impact of autocrine/paracrine than of endocrine IGF-I
}

\author{
Eppler, E ; Caelers, A ; Shved, N ; Hwang, G ; Rahman, A M ; Maclean, N ; Zapf, J ; Reinecke, M
}

\begin{abstract}
Several lines of growth hormone (GH)-overexpressing fish have been produced and analysed for growth and fertility parameters. However, only few data are available on the growth-promoting hormone insulin-like growth factor I (IGF-I) that mediates most effects of GH, and these are contradictory. Using quantitative real-time RT-PCR, radioimmunoassay, in situ hybridization, immunohistochemistry, and radiochromatography we investigated IGF-I and IGF binding proteins (IGFBPs) in an adult (17 months old) transgenic (GH-overexpressing) tilapia (Oreochromis niloticus). The transgenics showed an around 1.5-fold increase in length and an approximately 2.3-fold higher weight than the non-transgenics. Using radioimmunoassay, the serum IGF-I levels were lower $(6.22+/-0.75 \mathrm{ng} / \mathrm{ml})$ in transgenic than in wildtype $(15.01+/-1.49 \mathrm{ng} / \mathrm{ml})$ individuals $(\mathrm{P}=0.0012)$. Radioimmunoassayable IGF-I in transgenic liver was 4.2 -times higher than in wild-type $(16.0+/-2.21$ vs. $3.83+/-0.71 \mathrm{ng} / \mathrm{g}, \mathrm{P}=0.0017)$. No hepatocytes in wild-type but numerous hepatocytes in transgenic liver contained IGF-I-immunoreactivity. RT-PCR revealed a 1.4-times higher IGF-I mRNA expression in the liver of the transgenics $(10.51+/-0.82 \mathrm{vs}$. $7.3+/-0.49 \mathrm{pg} /$ microg total RNA, $\mathrm{P}=0.0032)$. In correspondence, in situ hybridization showed more IGF-I mRNA containing hepatocytes in the transgenics. A twofold elevated IGF-I mRNA expression was determined in the skeletal muscle of transgenics $(0.33+/-0.02$ vs. $0.16+/-0.01 \mathrm{pg} / \mathrm{microg}$ total RNA, $\mathrm{P}<0.0001)$. Both liver and serum of transgenics showed increased IGF-I binding. The increased IGFBP content in the liver may lead to retention of IGF-I, and/or the release of IGF-I into the circulation may be slower resulting in accumulation of IGF-I in the hepatocytes. Our results indicate that the enhanced growth of the transgenics likely is due to enhanced autocrine/paracrine action of IGF-I in extrahepatic sites, as shown here for skeletal muscle.
\end{abstract}

DOI: https://doi.org/10.1007/s11248-007-9093-z

Posted at the Zurich Open Repository and Archive, University of Zurich

ZORA URL: https://doi.org/10.5167/uzh-29954

Journal Article

Published Version

Originally published at:

Eppler, E; Caelers, A; Shved, N; Hwang, G; Rahman, A M; Maclean, N; Zapf, J; Reinecke, M (2007). Insulin-like growth factor I (IGF-I) in a growth-enhanced transgenic (GH-overexpressing) bony fish, the tilapia (Oreochromis niloticus): indication for a higher impact of autocrine/paracrine than of endocrine IGF-I. Transgenic Research, 16(4):479-489.

DOI: https://doi.org/10.1007/s11248-007-9093-z 


\title{
Insulin-like growth factor I (IGF-I) in a growth-enhanced transgenic (GH-overexpressing) bony fish, the tilapia (Oreochromis niloticus): indication for a higher impact of autocrine/paracrine than of endocrine IGF-I
}

\author{
Elisabeth Eppler · Antje Caelers • Natallia Shved • Guylin Hwang • \\ Azizur M. Rahman · Norman Maclean · Jürgen Zapf · Manfred Reinecke
}

Received: 1 December 2006/Accepted: 19 March 2007/Published online: 13 April 2007

(C) Springer Science+Business Media B.V. 2007

\begin{abstract}
Several lines of growth hormone (GH)overexpressing fish have been produced and analysed for growth and fertility parameters. However, only few data are available on the growth-promoting hormone insulin-like growth factor I (IGF-I) that mediates most effects of $\mathrm{GH}$, and these are contradictory. Using quantitative real-time RT-PCR, radioimmunoassay, in situ hybridization, immunohistochemistry, and radiochromatography we investigated IGF-I and IGF binding proteins (IGFBPs) in an adult (17 months old) transgenic (GH-overexpressing) tilapia (Oreochromis niloticus). The transgenics showed an around 1.5-fold increase in length and an approximately 2.3-fold higher weight than the non-transgenics. Using radioimmunoassay, the serum IGF-I levels were lower $(6.22 \pm 0.75 \mathrm{ng} / \mathrm{ml})$ in transgenic than in wild-type $(15.01 \pm 1.49 \mathrm{ng} / \mathrm{ml})$ individuals $(P=0.0012)$. Radioimmunoassayable IGF-I in transgenic liver was 4.2times higher than in wild-type $(16.0 \pm 2.21$ vs. $3.83 \pm 0.71 \mathrm{ng} / \mathrm{g}, P=0.0017)$. No hepatocytes in wild-type but numerous hepatocytes in transgenic liver
\end{abstract}

E. Eppler · A. Caelers · N. Shved · J. Zapf .

M. Reinecke $(\square)$

Division of Neuroendocrinology, Institute of Anatomy, University of Zürich, Winterthurerstr 190, 8057 Zürich, Switzerland

e-mail: reinecke@anatom.uzh.ch

G. Hwang · A. M. Rahman - N. Maclean

School of Biological Sciences, University of

Southampton, Southampton, Hampshire SO16 7PX, UK contained IGF-I-immunoreactivity. RT-PCR revealed a 1.4-times higher IGF-I mRNA expression in the liver of the transgenics $(10.51 \pm 0.82$ vs. $7.3 \pm 0.49 \mathrm{pg} / \mu \mathrm{g}$ total RNA, $P=0.0032)$. In correspondence, in situ hybridization showed more IGF-I mRNA containing hepatocytes in the transgenics. A twofold elevated IGF-I mRNA expression was determined in the skeletal muscle of transgenics $(0.33 \pm 0.02$ vs. $0.16 \pm 0.01 \mathrm{pg} / \mu \mathrm{g}$ total RNA, $P<0.0001)$. Both liver and serum of transgenics showed increased IGF-I binding. The increased IGFBP content in the liver may lead to retention of IGF-I, and/or the release of IGF-I into the circulation may be slower resulting in accumulation of IGF-I in the hepatocytes. Our results indicate that the enhanced growth of the transgenics likely is due to enhanced autocrine/paracrine action of IGF-I in extrahepatic sites, as shown here for skeletal muscle.

Keywords IGF-I $\cdot$ IGFBP $\cdot$ Liver $\cdot$ Serum $\cdot$ Skeletal muscle $\cdot$ Transgenic fish

\section{Introduction}

Insulin-like growth factor I (IGF-I) is a potent mitogenic hormone that induces growth and differentiation in a variety of target organs (Jones and Clemmons 1995; Reinecke and Collet 1998; Butler and LeRoith 2001). In mammals, IGF-I is mainly 
produced in the liver which is the principal source of endocrine IGF-I. The primary stimulus for the synthesis and secretion of liver IGF-I is growth hormone $(\mathrm{GH})$ released from the anterior pituitary (Reinecke et al. 2005).

Like in mammals, the major site of IGF-I gene expression in bony fish is liver (Duan 1998; Reinecke et al. 2005; Wood et al. 2005). High-affinity GH binding sites have been characterized in salmon and tilapia liver (Gray et al. 1992; Ng et al. 1992; Shepherd et al. 1997). In accordance, GH injections promoted liver IGF-I mRNA expression in salmonids and tilapia (e.g. Duan et al. 1993a; Moriyama 1995; Shamblott et al. 1995; Duguay et al. 1996; Shepherd et al. 1997; Guillén et al. 1998; Kajimura et al. 2001; Vong et al. 2003) and raised IGF-I plasma levels in salmonids, seabream and tilapia (e.g. Moriyama 1995; Shamblott et al. 1995; Guillén et al. 1998; Moriyama et al. 2000; Kajimura et al. 2001), which was accompanied by an increase in growth (Guillén et al. 1998). Similarly, GH also stimulates the expression of IGF-I mRNA in primary hepatocyte cultures of bony fish, such as salmonids (Duan et al. 1993a, b; Shamblott et al. 1995; Pierce et al. 2005) and tilapia Oreochromis mossambicus (Schmid et al. 2000). In adult Coho salmon, continuous infusion of bovine IGF-I increased growth rate and weight gain (McCormick et al. 1992), and plasma IGF-I levels and growth rate were significantly correlated in $O$. mossambicus (Kajimura et al. 2001; Uchida et al. 2003).

Several groups have produced different lines of transgenic fish (e.g. Devlin et al. 2000; Maclean et al. 2002; Rocha et al. 2004). Among the transgenic fish those carrying exogenous GH gene constructs constitute the majority. The obvious reason for this focus of interest is to improve fish growth in aquacultural food production (Zbikowska 2003). Mainly salmonids (Du et al. 1992; Devlin et al. 1994, 2000; Sundstrom et al. 2004), carp (Zhang et al. 1990), tilapia (Martinez et al. 1996; Rahman et al. 1998), and sea bream (Lu et al. 2002) have been used for genetically induced growth enhancement. On the other hand, GH-overexpressing fish are also considered as excellent models to study gene regulation and development (Amsterdam and Becker 2005). However, investigations on transgenic fish have almost exclusively dealt with growth parameters, fertility, and body and organ integrity (Maclean et al. 2002; Sundstrom et al. 2004).

The above referred studies demonstrate the stimulating action of GH on IGF-I-mediated growth in bony fish either by bolus injections of $\mathrm{GH}$ or by adding $\mathrm{GH}$ to the medium of primary hepatocyte cultures and, thus, deal with short-term effects of GH. In contrast, only one study has dealt with IGF-I in transgenic GH-overexpressing fish. In Coho salmon Oncorhynchus kisutch IGF-I serum levels were determined and gave contradictory results (Devlin et al. 2000): in one experiment they were slightly enhanced and in another slightly reduced. In order to investigate whether the severe enhancement in body growth in GH-overexpressing fish may be due to endocrine (liver-derived) IGF-I and/or enhanced IGFI expression in skeletal muscle we used a transgenic GH-overexpressing and age-matched wild-type tilapia (Oreochromis niloticus). The following parameters were analysed: (1) the expression level of IGF-I mRNA in liver and skeletal muscle using quantitative real-time PCR, (2) the concentration of IGF-I peptide in liver and serum by RIA, (3) the localization of IGF-I in liver at the mRNA level by in situ hybridization and at the peptide level by immunohistochemistry, and (4) the IGF-I binding proteins (IGFBPs) in liver and serum by radiochromatography.

\section{Material and methods}

Animals

The transgenic fish used in these experiments have been previously produced from crosses between a wild-type female $O$. niloticus and a G1 transgenic male. This line of growth-enhanced tilapia (C86) carries a single copy of a Chinook salmon Oncorhynchus tshawytscha GH gene spliced to an ocean pout Macrozoarces americanus antifreeze promoter (OPAFPcsGH) co-ligated with a carp beta actin/lacZ reporter gene construct, integrated into the tilapia genome (Rahman et al. 1998). Tilapia of the C86 strain and the non-transgenic siblings were bred at the University of Southampton. The fish were kept in fresh water tanks at $27 \pm 1{ }^{\circ} \mathrm{C}$ under a $12 \mathrm{~h} / 12 \mathrm{~h}$ light/ dark cycle and fed to satiation. Adult (17 months) 
transgenic (TG) and wild-type (WT) fish were used for the experiments. Fish were anaesthetized with 2phenoxy-ethanol (Sigma, St Louis, MO, USA) added to water, measured in weight and length, and the tissue samples excised. Principles of animal care and specific national laws were followed.

\section{Detection of transgene}

The transgenic or non-transgenic state of the individuals was detected by RT-PCR followed up by Southern Blotting. For PCR amplification an approximately $3 \mathrm{~mm} \times 2 \mathrm{~mm}$ fin clip was taken from the caudal fin and immediately frozen in liquid nitrogen. Genomic DNA was isolated. The standard procedures for isolation and purification of DNA (Rahman and Maclean 1992) and subsequent PCR and Southern Blotting were performed as described before (Rahman et al. 1998).

Tissue sampling and extraction

Liver ( $n=10 \mathrm{TG}, n=10 \mathrm{WT}$ ) and skeletal muscle ( $n=6 \mathrm{TG}, n=6 \mathrm{WT}$ ) specimens for RT-PCR were excised and immediately transferred into $1.5 \mathrm{ml}$ of the RNA-preserving reagent RNAlater ${ }^{\mathrm{TM}}$ (Ambion, Austin, USA). The samples were kept at $4{ }^{\circ} \mathrm{C}$ to promote inactivation of RNAses and later stored at $-20^{\circ} \mathrm{C}$ until RNA isolation. Total RNA was extracted using TRIzol reagent (GibcoBRL), treated with $1 \mathrm{U}$ of RQ1 RNAse-free DNase (Catalys AG, Wallisellen, Switzerland), resuspended in DEPC-treated $\mathrm{H}_{2} \mathrm{O}$ and stored at $-80^{\circ} \mathrm{C}$.

Absolute quantification of liver and skeletal muscle IGF-I gene expression by real-time PCR

Absolute quantification of liver and skeletal muscle IGF-I mRNA was performed as already described (Caelers et al. 2004). In brief, based on the gene sequences of $O$. mossambicus IGF-I (Reinecke et al. 1997), and O. niloticus $\beta$-actin as a housekeeping gene (Hwang et al. 2003), tilapia specific primers and probes for real-time RT-PCR were designed with the Primer Express software version 1.5 (PE Biosystems, Foster City, CA, USA). To create templates for in vitro transcription, a T7 phage polymerase promoter gene sequence was added by primer extension to the $5^{\prime}$ end of the antisense primers using conven- tional RT-PCR of $O$. niloticus liver total RNA. For cDNA synthesis, $5 \mu \mathrm{g}$ RNA were annealed with $1 \mu \mathrm{M}$ poly $(\mathrm{dT})$ primer (5'-CCTGAATTCTAGAGCTCAT(dT17)- $3^{\prime}$ ) for $5 \mathrm{~min}$ at $70^{\circ} \mathrm{C}$. The RNA/primer mix was incubated for $1 \mathrm{~h}$ at $37^{\circ} \mathrm{C}$ with $10 \mathrm{mM}$ dNTPs and $100 \mathrm{U}$ M-MLV-RTase (Promega) in $1 \times$ buffer. One microlitre aliquots of cDNA were added to $50 \mu \mathrm{l}$ PCR reaction using the Thermo-Start ${ }^{\mathrm{TM}} \mathrm{PCR}$ Master Mix (Abgene, NY, USA). Amplification conditions were optimized for a Stratagene RoboCycler Gradient 40: 1 cycle $10 \mathrm{~min}$ at $94^{\circ} \mathrm{C}, 1 \mathrm{~min}$ at $60^{\circ} \mathrm{C}, 2 \mathrm{~min}$ at $72^{\circ} \mathrm{C} ; 40$ cycles $1 \mathrm{~min}$ at $94^{\circ} \mathrm{C}, 1 \mathrm{~min}$ at $60^{\circ} \mathrm{C}, 2 \mathrm{~min}$ at $72^{\circ} \mathrm{C}$; final extension $10 \mathrm{~min}$ at $72^{\circ} \mathrm{C}$. PCR products including the $\mathrm{T} 7$ promoter gene sequence were sequenced and visualized on a $2.5 \%$ agarose gel. Standard cRNAs were generated by in vitro transcription using the T7-MEGAshortscript $^{\mathrm{TM}}$ Kit (Ambion), analysed by photospectrometry and UV-shadowing, and quantified by photospectrometry and dot blot. Defined amounts at tenfold dilutions were subjected to real-time PCR using a one-Step-RT-PCR Mastermix (Applied Biosystems, Rotkreuz, Switzerland). RT-step $\left(48^{\circ} \mathrm{C}\right.$, $30 \mathrm{~min})$ and denaturation step $\left(95^{\circ} \mathrm{C}, 10 \mathrm{~min}\right)$ were performed followed by 40 cycles $\left(95^{\circ} \mathrm{C}, 15 \mathrm{~s} ; 60^{\circ} \mathrm{C}\right.$, 1 min) in a single tube using ABI PRISM ${ }^{\mathrm{TM}} 7700$ Sequence Detection System Perkin Elmer (Applied Biosystems). Standard curves were generated based on the linear relationship between $C_{\mathrm{T}}$ value and logarithm of the starting amount. For measurements, tenfold diluted defined amounts of standard cRNA and $10 \mathrm{ng}$ of total RNA were subjected in parallel to real-time PCR under the same experimental settings. To calculate absolute amounts the different lengths of cRNA and mRNA were considered by a correction factor determined by division of lengths of IGF-I mRNA and cRNA (546 nt/70 nt $=7.8$ ).

Peptide extraction of serum and liver

Blood ( $n=5$ TG, $n=5 \mathrm{WT}$ ) was taken with a $1 \mathrm{ml}$ heparinized syringe from the caudal vein and collected in sterile $0.5 \mathrm{ml}$ tubes. The blood was centrifuged at $13,000 \mathrm{rpm}$ for $15 \mathrm{~min}$ at $4{ }^{\circ} \mathrm{C}$ and the serum removed and stored at $-20^{\circ} \mathrm{C}$ until use. $1 \mathrm{~g}$ of liver ( $n=5 \mathrm{TG}, n=5 \mathrm{WT}$ ) was homogenized with $5 \mathrm{ml} 0.1 \mathrm{M}$ sodium phosphate buffer $(\mathrm{pH} 7.0)$ and centrifuged at $10,000 \mathrm{~g}$ for $15 \mathrm{~min}$ at $4{ }^{\circ} \mathrm{C}$. The supernatant was removed with a Pasteur pipette, 
deep-frozen immediately, and stored at $-20^{\circ} \mathrm{C}$ until use. To dissociate IGF-I from the binding proteins, acid-ethanol extraction was performed as already described. In brief, $40 \mu \mathrm{l}$ of serum and liver homogenate, respectively, was thoroughly mixed with $160 \mu \mathrm{l}$ of an acid-ethanol extraction mix (87.5\% ethanol, $12.5 \% 2 \mathrm{M} \mathrm{HCl}, \mathrm{v} / \mathrm{v})$ and incubated for $30 \mathrm{~min}$ at room temperature. After neutralization with $0.885 \mathrm{M}$ Tris base, the extracts were centrifuged at $13,000 \mathrm{rpm}$ at $4{ }^{\circ} \mathrm{C}$ for $10 \mathrm{~min}$. $50 \mu \mathrm{l}$ of the supernatant was used for the IGF-I radioimmunoassay.

Radioimmunoassay in serum and liver

Serum and liver IGF-I was measured using the Fish IGF-I RIA kit for the tilapia O. mossambicus (GroPep Pty Ltd., Adelaide, Australia) with recombinant tilapia IGF-I as tracer and standard according to the protocol of the manufacturer.

Radiochromatography for IGFBPs in serum and liver

Radiochromatography was performed as described earlier (Zapf et al. 1975, 1989). Briefly, $0.2 \mathrm{ml}$ of pooled serum or liver homogenate was diluted with $0.3 \mathrm{ml}$ of Dulbecco's phosphate-buffered saline, $\mathrm{pH}$ 7.4, containing $\mathrm{NaN}_{3}$ and $500 \mathrm{U}$ of Trasylol (Bayer, Germany), and incubated for $24 \mathrm{~h}$ at $4{ }^{\circ} \mathrm{C}$ with ${ }^{125} \mathrm{I}$ labelled tilapia IGF-I $\left(2.5 \times 10^{5} \mathrm{CPM}\right.$, GroPep Ltd. $)$. The mixture was run through a Sephadex G-200 column $(2.1 \mathrm{~cm} \times 70 \mathrm{~cm})$ preequilibrated with Dulbecco's buffered saline, $\mathrm{pH} 7.4$, and the radioactivity of the collected fractions $(2.5 \mathrm{ml})$ was counted in a gamma-counter.

Preparation of probes for in situ hybridization

Probes were prepared as described (Schmid et al. 1999; Berishvili et al. 2006a, b). In brief, total RNA from tilapia liver was extracted with the Ultraspec Extraction Kit (ams, Lugano, Switzerland). For cDNA synthesis $5 \mu \mathrm{g}$ RNA was annealed with $1 \mu \mathrm{M}$ of a poly $(\mathrm{dT})$ primer (5' CCTGAATTCTAGAGCTCAT(dT17) $3^{\prime}$ ) for $3 \mathrm{~min}$ at $70^{\circ} \mathrm{C}$. The RNA/primer mix was incubated for $1 \mathrm{~h}$ at $37^{\circ} \mathrm{C}$ with $15 \mathrm{mM}$ dNTPs and $10 \mathrm{U}$ AMV-RTase (Pharmacia, Switzerland) in $1 \times$ reaction buffer $(50 \mathrm{mM}$ Tris- $\mathrm{HCl} / \mathrm{pH} 8.3,40 \mathrm{mM} \mathrm{KCl}$, $6 \mathrm{mM} \mathrm{MgCl} 2$ ). One microlitre cDNA was incubated with $1 \mu \mathrm{M}$ of sense (5'-GTCTGTGGAGAGCGAGGCT T T - $3^{\prime}$ ) and antisense ( $5^{\prime}$ AACCTTGGGTGCTCTTGGCATG- $3^{\prime}$ ) primers corresponding to the B- and E-domain, $200 \mu \mathrm{M}$ dNTPs, and $1 \mathrm{U}$ Taq-polymerase (Pharmacia) in $1 \times$ incubation buffer $(10 \mathrm{mM}$ Tris-HCl/pH 8, $50 \mathrm{mM} \mathrm{KCl}, 1.5 \mathrm{mM}$ $\mathrm{MgCl}_{2}, 0.001 \%$ gelatine). The amplification program was optimized for a Stratagene RoboCycler Gradient $40: 1$ cycle $10 \mathrm{~min}$ at $94^{\circ} \mathrm{C}, 1 \mathrm{~min}$ at $59^{\circ} \mathrm{C}, 2 \mathrm{~min}$ at $72^{\circ} \mathrm{C} ; 30$ cycles $1 \mathrm{~min}$ at $94^{\circ} \mathrm{C}, 1 \mathrm{~min}$ at $59^{\circ} \mathrm{C}$ and $2 \mathrm{~min}$ at $72^{\circ} \mathrm{C}$ followed by final extension for $5 \mathrm{~min}$ at $72^{\circ} \mathrm{C}$. PCR fragments were separated on a $2 \%$ agarose gel and eluted by the Gel Extraction Kit QIAquick (Qiagen, Switzerland). Thereafter, the PCR products were cloned in a pCR-Script SK(+) cloning vector using a kit (Stratagene, Heidelberg, Germany). Plasmids containing the gene sequence fragments were sequenced (Microsynth, Switzerland) and the sequences compared to database. The plasmids containing the specific inserts of IGF-I (207 bp) were used as templates for the synthesis of digoxigenin (DIG)-labelled RNA probes. Linearization was performed with EcoRI for T3- and NotI for T7-polymerase-driven transcription. One microgram of linearized plasmids was transcribed in vitro in the presence of DIG-UTP from T3 and T7 promotors to obtain antisense and sense (negative control) probes. Integrity of probes and efficiency of labelling were confirmed by dot blot and gel electrophoresis including blotting and incubation with antibody. Specificity of the probes has been demonstrated previously (Schmid et al. 1999; Berishvili et al. 2006a).

In situ hybridization

Liver preparations ( $n=3 \mathrm{WT}, n=3 \mathrm{TG}$ ) were fixed by immersion with $4 \%$ buffered formalin for $4 \mathrm{~h}$ at room temperature. Specimens were dehydrated in ascending series of ethanol and routinely embedded in paraplast $\left(58^{\circ} \mathrm{C}\right)$. Four micrometre sections were mounted on Super Frost Plus slides (Menzel-Gläser, Germany) and dried overnight at $42^{\circ} \mathrm{C}$. After dewaxing and rehydration, the sections were postfixed with 4\% paraformaldehyde and $0.1 \%$ glutaraldehyde in $1 \times$ PBS. In situ hybridization was performed as previously described (Schmid et al. 1999; Berishvili et al. 2006a, b). The following steps were carried out with DEPC-treated solutions in a humified chamber. The 
sections were digested with $0.02 \%$ proteinase $\mathrm{K}$ in $20 \mathrm{mM}$ Tris- $\mathrm{HCl} / \mathrm{pH} 7.4,2 \mathrm{mM} \mathrm{CaCl}_{2}$ for $10 \mathrm{~min}$ at $37^{\circ} \mathrm{C}$. Thereafter, sections were treated with $1.5 \%$ triethanolamine and $0.25 \%$ acetic anhydride for $10 \mathrm{~min}$ at room temperature and incubated with $50 \mu \mathrm{l}$ prehybridization solution per section for $3-4 \mathrm{~h}$ at $54^{\circ} \mathrm{C}$. Hybridization was performed overnight at $54^{\circ} \mathrm{C}$ with $30 \mu \mathrm{l}$ of hybridization buffer containing $10 \mathrm{ng}$ of sense or antisense probe previously denaturated for $5 \mathrm{~min}$ at $85^{\circ} \mathrm{C}$. Slides were washed for $15 \mathrm{~min}$ at room temperature in $2 \times \mathrm{SSC}$, and for $30 \mathrm{~min}$ at the specific hybridization temperature at descending concentrations of $\operatorname{SSC}(2 \times, 1 \times, 0.5 \times$, $0.2 \times)$. The alkaline-phosphatase-coupled anti-DIG antibody was diluted $1: 4,000$ in $1 \%$ blocking reagent (Roche-Diagnostics) in buffer P1 and sections were incubated for $1 \mathrm{~h}$ at room temperature in the dark. After washing twice in $\mathrm{P} 1$ for $15 \mathrm{~min}$, sections were treated with buffer P3, $5 \mathrm{mM}$ levamisole, and NBT/ BCIP stock solution (Roche Diagnostics). Colour development was carried out overnight at room temperature and stopped by rinse in tap water for 15 min. Sections were mounted with glycergel and photographed with a Zeiss Axioscope using the Axiovision software 3.1. (Zeiss, Zürich, Switzerland).

Immunohistochemical technique

Specimens for immunohistochemistry ( $n=3$ WT, $n=3$ TG) were immersed in Bouin's solution without acetic acid for $4 \mathrm{~h}$ at room temperature. Specimens were dehydrated in ascending series of ethanol and routinely embedded in paraplast $\left(58^{\circ} \mathrm{C}\right)$. Sections were cut at $4 \mu \mathrm{m}$, mounted onto glass slides and dried overnight at $42^{\circ} \mathrm{C}$. After dewaxing and rehydration unspecific binding was reduced by treatment with PBS (pH 7.4) containing $2 \%$ bovine serum albumine for $30 \mathrm{~min}$ at room temperature. Thereafter, the sections were incubated overnight with the rabbit antiserum 116 raised against human IGF-I (1:400) and washed repetitively in PBS. This antiserum specifically also stains IGF-I in fish as shown by absorption experiments (Reinecke et al. 1997; Schmid et al. 1999; Berishvili et al. 2006a, b). The IGF-I antiserum was detected by incubation with biotinylated goat anti-rabbit IgG (Bioscience Products, Emmenbrücke, Switzerland, 1:100) for $30 \mathrm{~min}$ at room temperature. After repetitive rinsing in PBS, the reactions were visualized with fluorescein-isothiocy- anate-conjugated streptavidin (Bioscience Products, 1:100) for $30 \mathrm{~min}$ at room temperature in the dark. Sections were mounted with glycergel and photographed with a Zeiss Axioscope using the Axiovision software 3.1.

Statistical analysis

Statistical analysis of the data was performed with a GraphPad Prism 4 program. This included a MannWhitney- $U$-test with a significance level of $5 \%$. All data are expressed as means \pm SEM.

\section{Results}

Fish size and weight

The 17-month old transgenic fish showed an approximately 1.5 -fold increase in head-tail length when compared to their non-transgenic siblings $(28.7 \pm 8.3$ vs. $18.5 \pm 6.2 \mathrm{~cm})$. The mean weights of the transgenics were around 2.3-fold higher than those of their non-transgenic siblings $(415.6 \pm 98 \mathrm{~g}$ and $184 \pm 64 \mathrm{~g}$, respectively).

\section{Measurement of IGF-I peptide and mRNA}

Using radioimmunoassay, the serum IGF-I levels were lower $(6.22 \pm 0.75 \mathrm{ng} / \mathrm{ml})$ in transgenic than in wild-type $(15.01 \pm 1.49 \mathrm{ng} / \mathrm{ml})$ individuals $(P=0.0012)$ (Fig. 1a). As measured by the same radioimmunoassay, the IGF-I concentration in liver amounted to $16.0 \pm 2.21 \mathrm{ng} / \mathrm{g}$ in transgenics and to $3.83 \pm 0.71 \mathrm{ng} / \mathrm{g}$ in wild-type animals $(P=0.0017)$ (Fig. 1b). Real-time PCR revealed a 1.4-times higher IGF-I mRNA expression in the liver of the transgenics $(10.51 \pm 0.82$ vs. $7.3 \pm 0.49 \mathrm{pg} / \mu \mathrm{g}$ total RNA, $P=0.0032$, Fig. 1c) and a twofold elevated IGF-I mRNA expression in the skeletal muscle $(0.33 \pm 0.02$ vs. $0.16 \pm 0.01 \mathrm{pg} / \mu \mathrm{g}$ total RNA, $P<0.0001$, Fig. 1d).

Localization of IGF-I mRNA and peptide

In situ hybridization with antisense DIG-labelled RNA probe specific for tilapia IGF-I revealed positive responses in liver whereas the sense RNA 

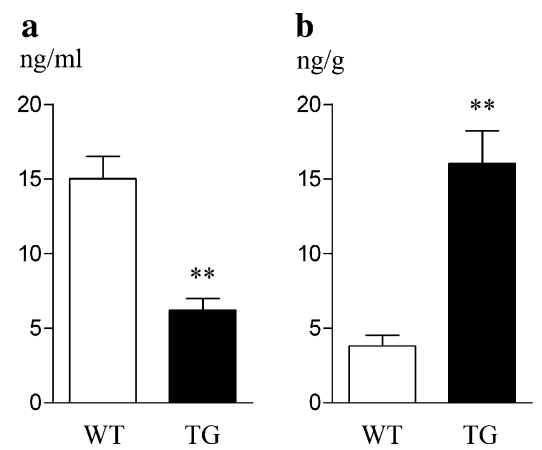

Fig. 1 (a, b) IGF-I peptide concentrations in serum (a) and liver (b) were determined by a species-specific RIA. IGF-I mRNA in liver (c) and muscle (d) were absolutely quantified by real-time PCR. Columns give mean values of $5(\mathbf{a}, \mathbf{b}), 10$ (c)

probe (negative control) showed no signals. In liver from non-transgenic tilapia, IGF-I mRNA occurred in numerous hepatocytes which were distributed in clusters throughout the parenchyma (Fig. 2a). Liver from transgenic individuals exhibited a higher degree of labelled cells. This was especially pronounced around the veins where numerous IGF-I mRNA containing hepatocytes were present (Fig. 2b).

In the liver of wild-type tilapia no IGF-I immunoreactivity was observed in hepatocytes (Fig. 2c). In contrast, numerous hepatocytes in transgenic liver contained IGF-I-immunoreactivity (Fig. 2d).
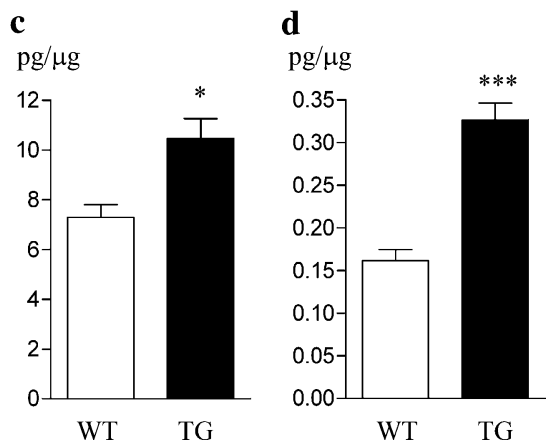

and 6 (d) individuals and bars give SEM. WT wild-type, $T G$ transgenics. Significance levels in Mann-Whitney- $U$-test: $* P=0.0032 ; * * P=0.0012, P=0.0017, * * * P<0.0001$

Determination of IGFBPs in serum and liver

Radiochromatography of serum from wild-type and transgenic tilapia gave two main radioactive peaks around fraction 61 and fraction 85 . In serum, the first peak, an IGF-binding peak corresponding to a molecular mass of $40-50 \mathrm{kDa}$, was about 1.6-fold higher in the transgenic than in the wild-type fish (Fig. 3a) as determined by planimetry. The second peak representing unbound ${ }^{125}$ I-IGF-I tracer was slightly higher for the wild-type serum, which is in line with the observed decreased binding of the tracer

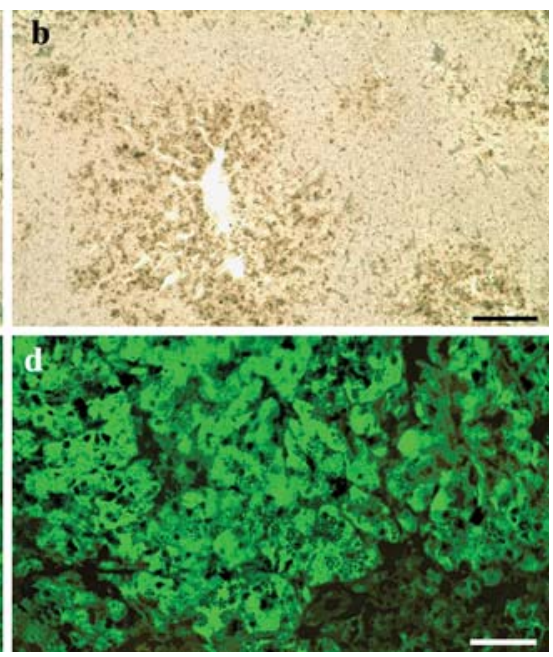

Fig. 2 IGF-I mRNA expression (a, b) and IGF-I immunoreactivity $(\mathbf{c}, \mathbf{d})$ in wild-type $(\mathbf{a}, \mathbf{c})$ and transgenic $(\mathbf{b}, \mathbf{d})$ tilapia liver. In situ hybridization was performed with antisense DIGlabelled RNA probe specific for tilapia IGF-I. Immunofluorescence used an IGF-I specific antiserum. In liver from wild-type tilapia, IGF-I mRNA is detected in numerous hepatocytes throughout the parenchyma (a) but no IGF-I peptide (c) is found. In liver from transgenic individuals, numerous IGF-I mRNA containing hepatocytes occur (b) and numerous hepatocytes contain IGF-I-immunoreactivity $(\mathbf{d}) \operatorname{Bar}(\mathbf{a}, \mathbf{b})$ $100 \mu \mathrm{m}, \operatorname{bar}(\mathbf{c}, \mathbf{d}) 20 \mu \mathrm{m}$ 

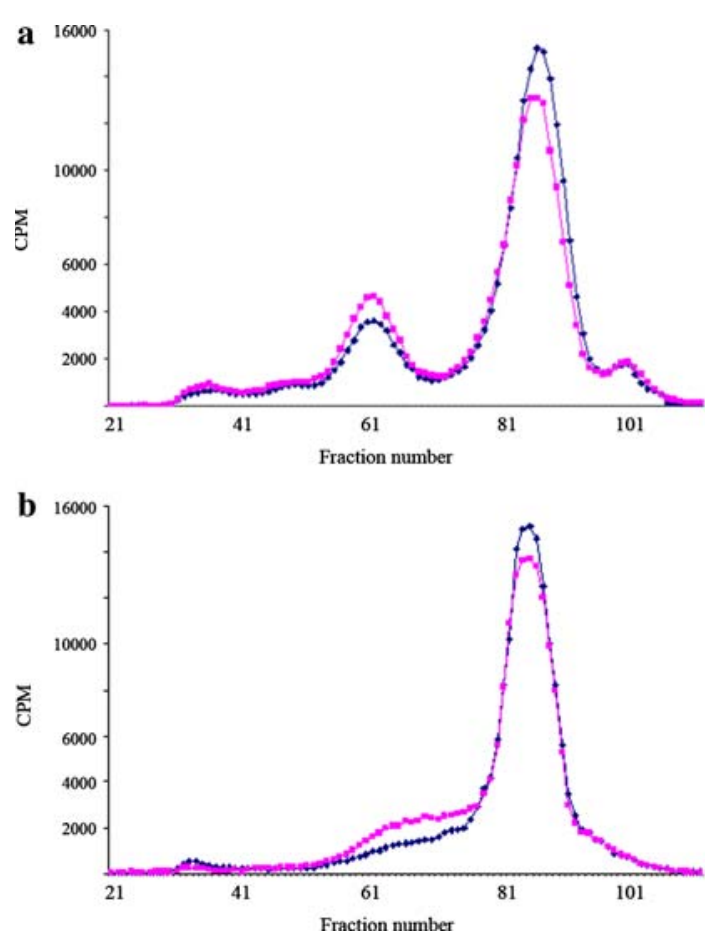

Fig. 3 Radiochromatography of a serum and b liver homogenate from wild-type (blue curve) and transgenic (red curve) tilapia. (a) The peak around fraction 61 corresponds to a molecular mass of $40-50 \mathrm{kDa}$. It is preceded by two minor peaks around fractions 34 and 48 . The peak around fraction 85 represents unbound 125I-IGF-I tracer. (b) The binding peak ("shoulder') elutes between fractions 57 and 70. The small peak around fraction 48 observed in serum (a) is not present in liver (b). CPM counts per minute

in the wild-type fish. The $40-50 \mathrm{kDa}$ binding peak disappeared when preincubation of the sera with the tracer was performed in the presence of excess cold IGF-I (not shown) indicating that binding was specific. At the same time, the peak of unbound tracer increased due to the inhibition of binding. Two minor peaks around fractions 34 and 48 preceded the 40-50 kDa binding peak (Fig. 3a). Similar to the latter, the peak around fraction 48 was displaced by cold IGF-I, but its height was not essentially different in wild-type and transgenic serum. In contrast, the radioactive peak around fraction 34 was not displaced by cold IGF-I indicating non-specific binding.

In the liver homogenate (Fig. 3b) a broader binding peak (a "shoulder" between fractions 57 and 70) was observed that was again higher (about 1.7-fold) in the transgenic than in the wild-type tilapia, whereas the reverse was true for the peak representing unbound tracer. Also here, binding disappeared in the presence of cold IGF-I (not shown). The small peak around fraction 48 observed in serum was not present in liver homogenate.

\section{Discussion}

When compared to their non-transgenic siblings neither the whole phenotype nor the inner organs of the transgenic tilapia of the C86 strain used here exhibited any obvious abnormalities (Maclean et al. 2002; Caelers et al. 2005). Food conversion efficiency was about $20 \%$ better in the transgenics and these turned out to be more efficient utilizers of protein and energy (Rahman et al. 1998). This is reflected by the 2.3 -fold higher mean body weight and the 1.5-fold higher mean body length of the 17month old transgenics investigated.

According to real-time PCR and in situ hybridization IGF-I was highly expressed in wild-type tilapia liver. These results correspond to those of previous PCR and Northern blot studies (e.g. Duan et al. 1993a, b; Duguay et al. 1996; Vong et al. 2003; Caelers et al. 2004) and studies using in situ hybridization (Schmid et al. 1999; Berishvili et al. 2006b) which have also reported a high content of IGF-I mRNA in bony fish liver. Despite the expression of IGF-I mRNA, no IGF-I-immunoreactive hepatocytes could be observed. Earlier studies have also failed to detect IGF-I-immunoreactivity in bony fish hepatocytes (Richardson et al. 1995; Reinecke et al. 1997). Because the same antiserum from the latter study detects IGF-I in numerous other organs of the tilapia (Reinecke et al. 1997; Schmid et al. 1999; Berishvili et al. 2006a, b) as well as in hepatocytes of the transgenics (this study), the negative result cannot be explained by the failure of the anti-mammalian IGF-I antiserum to crossreact with fish, as discussed by Plisetskaya (1998). Moreover, like in fish liver, IGFI-immunoreactivity could not be localized in rat liver but was detectable only after pretreatment with colchicine (Hansson et al. 1988). Thus, it is reasonable to assume that IGF-I after synthesis is rapidly released from the hepatocytes into the circulation (Reinecke et al. 1997; Plisetskaya 1998).

In the present study, radioimmunoassayable IGF-I in wild-type tilapia liver amounted to about $3.8 \mathrm{ng} / \mathrm{g}$ (0.5 pmol/g). Until now, no results have been 
reported for fish liver IGF-I measured with a speciesspecific RIA. A significantly (about fourfold) higher level of IGF-I was found in the liver of transgenics (16.0 ng/g; $2.1 \mathrm{pmol} / \mathrm{g}$ ). This is paralled by the detection of IGF-I-immunoreactive hepatocytes in transgenic liver which were not observed in wildtype, as well as by the increase in IGF-I mRNA expression as revealed by RT-PCR and in situ hybridization. Because the latter results may also indicate a higher release of IGF-I into the circulation the level of IGF-I in serum was determined. In wildtype individuals it amounted to $15 \mathrm{ng} / \mathrm{ml}(\sim 2 \mathrm{pmol} /$ $\mathrm{ml})$ whereas in the transgenics it was $6.2 \mathrm{ng} / \mathrm{ml}$ $(0.82 \mathrm{pmol} / \mathrm{ml})$. Comparison of the serum IGF-I levels published for diverse bony fish shows a broad range. The serum IGF-I concentration in wild-type $O$. niloticus as measured here $(15 \mathrm{ng} / \mathrm{ml})$ is lower than that reported in two previous studies on another tilapia species, O. mossambicus (150 ng/ml, Riley et al. 2002; $120 \mathrm{ng} / \mathrm{ml}$, Uchida et al. 2003), but consistent with recent data on $O$. mossambicus ( $\sim 20 \mathrm{ng} / \mathrm{ml}$, Fiess et al. 2007) obtained under similar rearing conditions $\left(28^{\circ} \mathrm{C}\right.$, freshwater, feeding) as used here, and on rainbow trout $(11.5 \mathrm{ng} / \mathrm{ml}$, Gabillard et al. 2003), brown trout $(42.2 \mathrm{ng} / \mathrm{ml}$, Baños et al. 1999), Atlantic (53.1 ng/ml, Dyer et al. 2004) and Coho salmon (7.5-14 ng/ml, Shimizu et al. 1999; $25.9 \mathrm{ng} / \mathrm{ml}$, Shimizu et al. 2000; 45.2-85 ng/ml, Moriyama 1995). In Coho salmon (Shimizu et al. 2003) and gilthead seabream (Mingarro et al. 2002), plasma IGF-I levels changed with the seasons and were higher in fed fish reared in a warm environment $(10-15 \mathrm{ng} / \mathrm{ml})$ than in starved fish reared in the cold (5-9 ng/ml, Larsen et al. 2001). In several salmonids, liver IGF-I mRNA and/or plasma IGF-I levels were related to environmental temperature (Gabillard et al. 2003; Larsen et al. 2001; Beckman et al. 1998). The largely varying serum IGF-I levels in bony fish may, thus, be due to species differences but may as well reflect physiological parameters such as nutritional status, seasons and environmental temperature (Reinecke and Collet 1998; Duan 1998; Reinecke et al. 2005).

As a first step towards identifying specific IGF-I binding (IGF binding proteins) in tilapia serum and liver we used incubation with ${ }^{125}$ I-IGF-I and subsequent gel filtration at neutral $\mathrm{pH}$ (radiochromatography). The main ${ }^{125}$ I-IGF-I binding peak of tilapia serum eluted at the same position
(40-50 kDa) as in human serum (Zapf et al. 1975). In human serum, this peak contains all six IGFBPs, BP-1 to BP-6 (Zapf 1995). It is likely that the five IGFBPs detected in fish serum so far (Duan and Xu 2005; Shimizu et al. 2005; Kelley et al. 2002, 2006) are also located in this binding complex. Serum of the transgenics bound more tracer than wild-type serum. The height of the binding peak is determined by two factors, the amount of binding protein and its IGF content. Increased binding of ${ }^{125}$ I-IGF-I in the transgenic serum could therefore be due to its lower IGF-I concentration resulting in a greater residual binding capacity or to a higher IGFBP concentration. In agreement with the increased binding of ${ }^{125}$ I-IGF-I in the serum of the transgenic (GH-overexpressing) tilapia, short-term application of $\mathrm{GH}$ has been shown to up-regulate the BP serum levels in Coho salmon (Shimizu et al. 1999; Kelley et al. 1992), striped bass (Siharath et al. 1995) and tilapia (O. mossambicus; Park et al. 2000).

Whereas the radiochromatographic pattern of human serum displays an IGF binding peak at $150 \mathrm{kDa}$ (Zapf et al. 1975) consisting of a ternary complex of IGFBP-3, IGF-I and -II, and an acidlabile subunit (ALS, Baxter et al. 1989), the tested tilapia serum showed only a minor binding peak in the $150 \mathrm{kDa}$ region. Whether this peak corresponds to the ternary complex of mammalian serum is not clear. However, no evidence for a ternary complex has so far been obtained in fish serum (Kelley et al. 2006).

In contrast to serum, the protein-bound radioactivity in tilapia liver homogenate eluted as a relatively broad shoulder. It was shifted towards the peak of non-bound tracer and, thus, apparently contained also IGFBPs of smaller molecular weight or IGFBP degradation products. The observed increased binding of tracer in transgenic liver is compatible with a greater binding protein content than in wild-type liver because the IGF-I concentration in the transgenic liver was higher and binding capacity would therefore be expected to be lower.

In GH-overexpressing Coho salmon, IGF-I serum levels varied (Devlin et al. 2000): they were either slightly enhanced or slightly reduced. Our finding that the IGF-I serum levels in the growth-enhanced transgenic tilapia were significantly by $60 \%$ lower than in wild-type fish, despite increased IGF-I mRNA expression and peptide levels in liver, was unexpected. This observation appears to be in contrast to 
results obtained in O. mossambicus demonstrating that body length and mass are positively correlated with the plasma IGF-I concentration (Kajimura et al. 2001; Uchida et al. 2003). Moreover, a clear correlation between individual serum IGF-I levels and growth rates has been established in Coho salmon (Pierce et al. 2001). How could the lower IGF-I serum levels in the transgenic animals be explained? The increased content of IGFBPs in the liver of the transgenics may lead to retention of IGF-I by these BPs. This is further supported by the finding that IGF-I-immunoreactivity was present in hepatocytes of transgenic but not of wild-type liver.

In addition then, the question arises why transgenic tilapia have an approximately 1.5 -fold greater body length and a 2.3-fold higher body weight than the wild-type despite lower serum IGF-I. Recent studies using the Cre/loxP recombination system to delete the IGF-I gene exclusively in the liver of mice (Sjögren et al. 1999; Yakar et al. 1999) underline the potential importance of local IGF-I production for growth. Despite deletion of liver IGF-I mRNA expression and largely reduced levels of circulating IGF-I, the animals did not show any obvious impairment of postnatal body growth. Similarly, in the transgenic tilapia, IGF-I in extrahepatic sites may determine the growth rate. This has been shown here to be true for skeletal muscle that is essentially involved in growth. Enhanced growth therefore seems to be caused by higher tissue levels of IGF-I under the influence of the GH transgene and thus by autocrine/paracrine actions of IGF-I.

Acknowledgements The authors are grateful to Ms Cornelia Zwimpfer, Division of Endocrinology and Diabetes, Department of Medicine, University Hospital Zürich, for excellent support in the performance of radioimmunoassay and radiochromatography. The study was supported by the Swiss National Science Foundation (grant no. 111028) and the Hartmann Müller-Foundation for Medical Research (grant no. 1115).

\section{References}

Amsterdam A, Becker TS (2005) Transgenes as screening tools to probe and manipulate the zebrafish genome. Dev Dyn 234:255-268

Baños N, Planas JV, Gutiérrez J, Navarro I (1999) Regulation of plasma insulin-like growth factor-I levels in brown trout (Salmo trutta). Comp Biochem Physiol C Pharmacol Toxicol Endocrinol 124:33-40
Baxter RC, Martin JL, Beniac V (1989) High molecular weight insulin-like growth factor binding protein complex. Purification and properties of the acid-labile subunit from human serum. J Biol Chem 264:11843-11848

Beckman BR, Larsen DA, Moriyama S, Lee-Pawlak B, Dickhoff WW (1998) Insulin-like growth factor-I and environmental modulation of growth during smoltification of spring chinook salmon (Oncorhynchus tshawystscha). Gen Comp Endocrinol 109:325-335

Berishvili G, D'Cotta H, Baroiller J-F, Segner H, Reinecke M (2006a) Differential expression of IGF-I mRNA and peptide in the male and female gonad during early development of a bony fish, the tilapia Oreochromis niloticus. Gen Comp Endocrinol 146:204-210

Berishvili G, Shved N, Eppler E, Clotà F, Baroiller JF, Reinecke M (2006b) Organ-specific expression of IGF-I during early development of bony fish as revealed in the tilapia, Oreochromis niloticus, by in situ hybridization and immunohistochemistry: indication for the particular importance of local IGF-I. Cell Tissue Res 325:287-301

Butler A, LeRoith D (2001) Minireview: tissue-specific versus generalized gene targeting of the igf1 and igf1r genes and their roles in insulin-like growth factor physiology. Endocrinology 142:1685-1688

Caelers A, Berishvili G, Meli ML, Eppler E, Reinecke M (2004) Establishment of a real-time RT-PCR for the determination of absolute amounts of IGF-I and IGF-II gene expression in liver and extrahepatic sites of the tilapia. Gen Comp Endocrinol 137:196-204

Caelers A, Mclean N, Hwang G, Eppler E, Reinecke M (2005) Expression of endogenous and exogenous growth hormone (GH) messenger (m) RNA in a GH-transgenic tilapia (Oreochromis niloticus). Transgenic Res 14:95-104

Devlin RH, Vesaki TY, Biagi CA, Donaldson EM, Swanson P, Chan W-K (1994) Extraordinary salmon growth. Nature 371:209-210

Devlin RH, Swanson P, Clarke WC, Plisetskaya E, Dickhoff W, Moriyama S, Yesaki TY, Hew C-L (2000) Seawater adaptability and hormone levels in growth-enhanced transgenic coho salmon, Oncorhynchus kisutch. Aquaculture 191:367-385

Du SJ, Gong ZY, Fletcher GL, Shears MA, King MJ, Idler DR, Hew CL (1992) Growth enhancement in transgenic Atlantic salmon by the use of an "all fish" chimeric growth hormone gene construct. Biotechnology (NY) 10:176-181

Duan C (1998) Nutritional and developmental regulation of insulin-like growth factors in fish. J Nutr 128(Suppl 2):306S-314S

Duan C, Xu Q (2005) Roles of insulin-like growth factor (IGF) binding proteins in regulating IGF actions. Gen Comp Endocrinol 142:44-52

Duan C, Duguay SJ, Plisetskaya EM (1993a) Insulin-like growth factor (IGF-I) mRNA expression in coho salmon, Oncorhynchus kisutch: tissue distribution and effects of growth hormone/prolactin family proteins. Fish Physiol Biochem 11:371-379

Duan C, Hanzawa N, Takeuchi Y, Hamada E, Miyachi S, Hirano T (1993b) Use of primary cultures of salmon hepatocytes for the study of hormonal regulation of IGF-I expression in vitro. Zool Sci 10:473-480 
Duguay SJ, Lai-Zhang J, Steiner DF, Funkenstein B, Chan SJ (1996) Developmental and tissue-regulated expression of IGF-I and IGF-II mRNAs in Sparus aurata. J Mol Endocrinol 16:123-132

Dyer AR, Upton Z, Stone D, Thomas PM, Soole KL, Higgs N, Quinn K, Carragher JF (2004) Development and validation of a radioimmunoassay for fish insulin-like growth factor I (IGF-I) and the effect of aquaculture related stressors on circulating IGF-I levels. Gen Comp Endocrinol 135:268-275

Fiess JC, Kunkel-Patterson A, Mathias L, Riley LG, Yancey PH, Hirano T, Grau EG (2007) Effects of environmental salinity and temperature on osmoregulatory ability, organic osmolytes, and plasma hormone profiles in the Mozambique tilapia (Oreochromis mossambicus). Comp Biochem Physiol A Mol Integr Physiol 146:252-264

Gabillard JC, Weil C, Rescan PY, Navarro I, Gutierrez J, Le Bail PY (2003) Effects of environmental temperature on IGF1, IGF2, and IGF type I receptor expression in rainbow trout (Oncorhynchus mykiss). Gen Comp Endocrinol 133:233-242

Gray ES, Kelley KM, Law S, Tsai R, Young G, Bern H (1992) Regulation of hepatic growth hormone receptors in coho salmon (Oncorhynchus kisutch). Gen Comp Endocrinol $88: 243-252$

Guillén II, Lleonart R, Agramonte A, Morales R, Morales A, Hernandez CA, Vazquez MM, Diaz M, Herrera MT, Alvarez-Lajonchere L, Hernandez O, de la Fuente J (1998) Physiological changes in the juvenile euryhaline teleost, the tilapia Oreochromis hornorum, injected with E. coli-derived homologous growth hormone. J Mar Biotechnol 6:142-151

Hansson H-A, Nilsson A, Isgaard J, Billig H, Isaksson O, Skottner A, Andersson IK, Rozell B (1988) Immunohistochemical localization of insulin-like growth factor I in the adult rat. Histochemistry 89:403-410

Hwang GL, Rahman MA, Abdul Razak S, Sohm F, Farahmand H, Smith A, Brooks C, Maclean N (2003) Isolation and characterisation of tilapia beta-actin promoter and comparison of its activity with carp beta-actin promoter. Biochim Biophys Acta 1625:11-18

Jones JI, Clemmons DR (1995) Insulin-like growth factors and their binding proteins: biological actions. Endocr Rev 16:3-34

Kajimura S, Uchida K, Yada T, Riley LG, Byatt JC, Colloier RJ, Aida K, Hirano T, Grau EG (2001) Stimulation of insulin-like growth factor-I production by recombinant bovine growth hormone in Mozambique tilapia, Oreochromis mossambicus. Fish Physiol Biochem 25:221230

Kelley KM, Siharath K, Bern HA (1992) Identification of insulin-like growth factor-binding proteins in the circulation of four teleost fish species. J Exp Zool 263:220-224

Kelley KM, Schmidt KE, Berg L, Sak K, Galima MM, Gillespie C, Balogh L, Hawayek A, Reyes JA, Jamison M (2002) Comparative endocrinology of the insulin-like growth factor-binding protein. J Endocrinol 175:3-18

Kelley KM, Price TD, Galima MM, Sak K, Reyes JA, Zepeda O, Hagstrom R, Tuan A, Truong TA, Lowe CG (2006) Insulin-like growth factor binding proteins (IGFBPs) in fish: beacons for (disrupted) growth endocrine physiology.
In: Reinecke M, Zaccone G, Kapoor BG (eds) Fish endocrinolgy. Science Publishers, Enfield, pp 167-195

Larsen DA, Beckman BR, Dickhoff WW (2001) The effect of low temperature and fasting during the winter on metabolic stores and endocrine physiology (insulin, insulinlike growth factor-I, and thyroxine) of coho salmon, Oncorhynchus kisutch. Gen Comp Endocrinol 123:308-323

Lu JK, Fu BH, Wu JL, Chen TT (2002) Production of transgenic silver sea bream (Sparus sarba) by different gene transfer methods. Mar Biotechnol (NY) 4:328-337

Maclean N, Rahman MA, Sohm F, Hwang G, Iyengar A, Ayad H, Smith A, Farahmand H (2002) Transgenic tilapia and the tilapia genome. Gene 295:265-277

Martinez R, Estrada MP, Berlanga J, Guillén I, Hernandez O, Cabrera E, Pimentel R, Morales R, Herrera F, Morales A, Pina JC, Abad Z, Sanchez V, Melamed P, Lleonart R, de la Fuente J (1996) Growth enhancement in transgenic tilapia by ectopic expression of tilapia growth hormone. Mol Mar Biol Biotechnol 5:62-70

McCormick SD, Kelley KM, Young G, Nishioka RS, Bern HA (1992) Stimulation of coho salmon growth by insulin-like growth factor I. Gen Comp Endocrinol 86:398-406

Mingarro M, Vega-Rubin de Celis S, Astola A, Pendon C, Valdivia MM, Perez-Sanchez J (2002) Endocrine mediators of seasonal growth in gilthead sea bream (Sparus aurata): the growth hormone and somatolactin paradigm. Gen Comp Endocrinol 128:102-111

Moriyama S (1995) Increased plasma insulin-like growth factor-I (IGF-I) following oral and intraperitoneal administration of growth hormone to rainbow trout, Oncorhynchus mykiss. Growth Regul 5:164-167

Moriyama S, Ayson FG, Kawauchi H (2000) Growth regulation by insulin-like growth factor-I in fish. Biosci Biotechnol Biochem 64:1553-1562

Ng TB, Leung TC, Cheng CHK, Woo NY (1992) Growth hormone binding sites in tilapia (Oreochromis mossambicus) liver. Gen Comp Endocrinol 86:111-118

Park R, Shepherd BS, Nishioka RS, Grau EG, Bern HA (2000) Effects of homologous pituitary hormone treatment on serum insulin-like growth factor-binding proteins (IGFBPs) in hypophysectomized tilapia, Oreochromis mossambicus, with special reference to a novel 20-kDa IGFBP. Gen Comp Endocrinol 117:404-412

Pierce AL, Beckman BR, Shearer KD, Larsen DA, Dickhoff WW (2001) Effects of ration on somatotropic hormones and growth in coho salmon. Comp Biochem Physiol B Biochem Mol Biol 128:255-264

Pierce AL, Fukada H, Dickhoff WW (2005) Metabolic hormones modulate the effect of growth hormone $(\mathrm{GH})$ on insulin-like growth factor-I (IGF-I) mRNA level in primary culture of salmon hepatocytes. J Endocrinol 184:341-349

Plisetskaya EM (1998) Some of my not so favorite things about insulin and insulin-like growth factors in fish. Comp Biochem Physiol B Biochem Mol Biol 121:3-11

Rahman A, Maclean N (1992) Fish transgene expression by direct injection into fish muscle. Mol Mar Biol Biotechnol 1:286-289

Rahman MA, Mak R, Ayad H, Smith A, Maclean N (1998) Expression of a novel piscine growth hormone gene results in growth enhancement in transgenic tilapia (Oreochromis niloticus). Transgenic Res 7:357-369 
Reinecke M, Collet C (1998) The phylogeny of the insulin-like growth factors. Int Rev Cytol 183:1-94

Reinecke M, Schmid A, Ermatinger R, Loffing-Cueni D (1997) Insulin-like growth factor I in the teleost Oreochromis mossambicus, the tilapia: gene sequence, tissue expression, and cellular localization. Endocrinology 138:36133619

Reinecke M, Björnsson TB, Dickhoff WW, McCormick SD, Navarro I, Power DM, Gutiérrez J (2005) Growth hormone and insulin-like growth factors in fish: where we are and where to go. Gen Comp Endocrinol 142:20-24

Richardson NA, Anderson AJ, Rimmer MA, Sara VR (1995) Localization of insulin-like growth factor-I immunoreactivity in larval and juvenile barramundi (Lates calcarifer). Gen Comp Endocrinol 100:282-292

Riley LG, Richman NH 3rd, Hirano T, Grau EG (2002) Activation of the growth hormone/insulin-like growth factor axis by treatment with 17 alpha-methyltestosterone and seawater rearing in the tilapia, Oreochromis mossambicus. Gen Comp Endocrinol 127:285-292

Rocha A, Ruiz S, Estepa A, Coll JM (2004) Application of inducible and targeted gene strategies to produce transgenic fish: a review. Mar Biotechnol (NY) 6:118-127

Schmid AC, Naef E, Kloas W, Reinecke M (1999) IGF-I and IGF-II in the ovary of a bony fish Oreochromis mossambicus, the tilapia: In situ hybridization, immunohistochemical localisation, Northern Blot and cDNA sequences. Mol Cell Endocrinol 156:141-149

Schmid AC, Reinecke M, Kloas W (2000) Primary cultured hepatocytes of the bony fish, Oreochromis mossambicus, the tilapia: a valid tool for physiological studies on IGF-I expression in liver. J Endocrinol 166:265-273

Shamblott MJ, Cheng CM, Bolt D, Chen TT (1995) Appearance of insulin-like growth factor mRNA in the liver and pyloric ceca of a teleost in response to exogenous growth hormone. Proc Natl Acad Sci USA 92:6943-6946

Shepherd BS, Sakamoto T, Nishioka RS, Richman NH III, Mori I, Madsen SS, Chen TT, Hirano T, Bern HA, Grau EG (1997) Somatotrophic actions of homologous growth hormone and prolactins in the euryhyaline teleost, the tilapia, Oreochromis mossambicus. Proc Natl Acad Sci USA 94:2068-2072

Shimizu M, Swanson P, Dickhoff WW (1999) Free and protein-bound insulin-like growth factor-I (IGF-I) and IGFbinding proteins in plasma of coho salmon, Oncorhynchus kisutch. Gen Comp Endocrinol 115:398-405

Shimizu M, Swanson P, Fukuda H, Hara A, Dickhoff WW (2000) Comparison of extraction methods and assay validation for salmon insulin-like growth factor-I using commercially available components. Gen Comp Endocrinol 119:26-36

Shimizu M, Hara A, Dickhoff WW (2003) Development of an RIA for salmon $41 \mathrm{kDa}$ IGF-binding protein. J Endocrinol 178:275-283
Shimizu M, Dickey JT, Fukada H, Dickhoff WW (2005) Salmon serum $22 \mathrm{kDa}$ insulin-like growth factor-binding protein (IGFBP) is IGFBP-1. J Endocrinol 184:267-276

Siharath K, Nishioka RS, Madsen SS, Bern HA (1995) Regulation of IGF-binding proteins by growth hormone in the striped bass, Morone saxatilis. Mol Mar Biol Biotechnol 4:171-178

Sjögren K, Liu J-L, Blad K, Skrtic S, Vidal O, Wallenius V, Le Roith D, Törnell J, Isaksson OPG, Jansson J-O, Ohlsson C (1999) Liver-derived insulin-like growth factor I (IGF-I) is the pricipal source of IGF-I in blood but is not required for postnatal body growth in mice. Proc Natl Acad Sci USA 96:7088-7092

Sundstrom LF, Lohmus M, Johnsson JI, Devlin RH (2004) Growth hormone transgenic salmon pay for growth potential with increased predation mortality. Proc Biol Sci 271(Suppl 5):S350-S352

Uchida K, Kajimura S, Riley LG, Hirano T, Aida K, Grau EG (2003) Effects of fasting on growth hormone/insulin-like growth factor I axis in the tilapia, Oreochromis mossambicus. Comp Biochem Physiol A Mol Integr Physiol 134:429-433

Vong QP, Chan KM, Cheng CH (2003) Quantification of common carp (Cyprinus carpio) IGF-I and IGF-II mRNA by real-time PCR: differential regulation of expression by GH. J Endocrinol 178:513-521

Wood AW, Duan C, Bern HA (2005) Insulin-like growth factor signaling in fish. Int Rev Cytol 243:215-285

Yakar S, Liu J-L, Stannard B, Butler A, Accili D, Sauer B, LeRoith D (1999) Normal growth and development in the absence of hepatic insulin-like growth factor I. Proc Natl Acad Sci USA 96:7324-7329

Zapf J (1995) Physiological role of the insulin-like growth factor binding proteins. Eur J Endocrinol 132:645-654

Zapf J, Waldvogel M, Froesch ER (1975) Binding of nonsuppressible insulin-like activity to human serum. Arch Biochem Biophys 168:638-645

Zapf J, Hauri C, Waldvogel M, Futo E, Häsler H, Binz K, Guler HP, Schmid C, Froesch ER (1989) Recombinant human insulin-like growth factor I induces its own specific carrier protein in hypophysectomized and diabetic rats. Proc Natl Acad Sci USA 86:3813-3817

Zbikowska HM (2003) Fish can be first-advances in fish transgenesis for commercial applications. Transgenic Res 12:379-389

Zhang PJ, Hayat M, Joyce C, Gonzalez-Villasenor LI, Lin CM, Dunham RA, Chen TT, Powers DA (1990) Gene transfer, expression and inheritance of pRSV-rainbow trout-GH cDNA in the common carp, Cyprinus carpio (Linnaeus). Mol Reprod Dev 25:3-13 